\title{
Native Argentinean cyclopoids (Crustacea: Copepoda) as predators of Aedes aegypti and Culex pipiens (Diptera: Culicidae) mosquitoes
}

\author{
María C. Tranchida ${ }^{1 *}$, María V. Micieli ${ }^{1,2}$, Arnaldo Maciá $^{1,3}$ \& Juan J. García ${ }^{1,4}$ \\ 1. Centro de Estudios Parasitológicos y de Vectores, CEPAVE, (CCT-La Plata-CONICET-UNLP), Calle 2 n $^{\circ} 584$, (1900) \\ La Plata, Buenos Aires, Argentina; *Corresponding author: ctranchida@cepave.edu.ar \\ 2.rvmicieli@fcnym.unlp.edu.ar \\ 3. Researcher assistant CIC: amacia@cepave.edu.ar \\ 4. Researcher CIC:juan@cepave.edu.ar
}

Received 13-VI-2008. Corrected 12-II-2009. Accepted 13-III-2009.

\begin{abstract}
Copepods from La Plata, Argentina were investigated to characterize the local community of larvivorous copepods inhabiting mosquito breeding sites and to identify new predator species of the mosquitoes which occur in artificial containers, Aedes aegypti and Culex pipiens. Diversity of larvivorous cyclopoids was highest in permanent pools. Predation by sex and age, selectivity on mosquito species, and daily predation rate during five days were studied for Acanthocyclops robustus, Diacyclops uruguayensis, Macrocyclops albidus and Mesocyclops longisetus. Female copepods presented the highest predatory capacity. No predatory preference for mosquito species was found. According to overall predation potential, copepods were ranked as follows: D. uruguayensis $<A$. robustus $<M$. albidus $<M$. longisetus. Copepod tolerance to desiccation and capacity to survive in water from artificial containers were also evaluated. D. uruguayensis and $A$. robustus survived under dry conditions, but $D$. uruguayensis showed lower survival in water from cemetery flower vases. M. albidus did not survive under dry conditions and did not tolerate water extracted from artificial containers. M. longisetus survival was not severely reduced after desiccation or breeding in water from flower vases. The Neotropical cyclopoids D. uruguayensis and A. robustus can be considered good candidates and merit further research as biological control agents for mosquitoes. Rev. Biol. Trop. 57 (4): 1059-1068. Epub 2009 December 01.
\end{abstract}

Key words: Copepoda, mosquitoes, larval predation, biological control, Argentina.

Cyclopoid copepods are important members of freshwater communities, being the most abundant consumers among planktonic taxa. Many species of copepods have been shown to kill mosquito larvae (Suarez et al. 1984, Riviere et al. 1987, Marten 1989, 1990a, 1990b, Marten et al. 1994, Brown et al. 1991), the group has been regarded as the most efficient among all invertebrate predators of Culicidae (Marten and Reid 2007). Field studies on mosquito control using copepods have been carried out mainly on man-made water containers (Marten and Reid 2007), with successful results in some cases (Marten et al. 1994,
Gorrochotegui-Escalante et al. 1998, Nam et al. 2000). These studies have shown that some cyclopoids are appropriate to be incorporated into programs to combat particular vectors, or to lower their population levels. It is advisable to gather further information regarding new, local species of copepods before implementing their use as biological control agents.

In Argentina, no extensive survey of the local copepod fauna has been undertaken to the present in order to search for new potential predator species. Only a single species, Mesocyclops annulatus Wierzejski, has been assessed in laboratory trials (Micieli et al. 2002), and 
under semi-natural conditions (Marti et al. 2004), in which it has proven to be an effective predator of early instars of Aedes aegypti L. However, tests are required for other species of copepods of unknown potential as mosquito predators. Herein we present information on the potential of some copepods native to Argentina for mosquito control. In order to establish which species of copepods are abundant in mosquito breeding places from urban environments, a field survey was carried out in the area of La Plata city, Buenos Aires province, Argentina. Subsequently we performed laboratory evaluations of the potential of some copepods as predators of the most common mosquitoes occurring in artificial receptacles, namely $A$. aegypti and Culex pipiens L. Our main interest is focused on these species because they frequently co-occur in artificial water containers near human environments and are also important vectors of human pathogens.

\section{MATERIAL AND METHODS}

Study area: Field survey was conducted in and near La Plata city (3451'07' S, 58 57'30' W). Several types of mosquito breeding sites were sampled to detect cohabitation in space and time of mosquito species and copepods. The surveyed freshwater sites were grouped into the following categories: a- Transient freshwater ponds: three shallow depressions in the ground, ranging from 20 to $100 \mathrm{~m}^{2}$, filled by rainfall and lasting from several days up to five weeks. b- Permanent pools: two pools with floating vegetation, approximate size $25 \mathrm{~m}$ long, $25 \mathrm{~m}$ wide and $1 \mathrm{~m}$ depth each. c-Drainage ditches $(25 \mathrm{~m}$ long, $0.5 \mathrm{~m}$ wide and $0.4 \mathrm{~m}$ deep) located in a suburban area of La Plata city. d- Rice fields: large fields with several irrigation canals each, occupied by rice crops, artificially flooded in December and maintained under water until April. After that, the fields remain flooded for a variable period according to environmental temperature and rains. Only one flooded rice field was selected and 40 internal irrigation canals $(20 \mathrm{~m}$ long, $0.25 \mathrm{~m}$ wide, $0.15 \mathrm{~m}$ deep) were sampled. e- Artificial containers: flower vases made of zinc or ceramic, with approximately $1 \mathrm{~L}$ capacity from a cemetery in La Plata City, and discarded vehicle tires from the city suburbs. f- Natural containers: water-filled leaf axils of Eryngium cabrerae Pontiroli plants (Apiaceae) which are common in non-cropped fields surrounding the city.

Collection of mosquitoes and copepods was carried out weekly during summer, using a $15 \times 10 \times 15 \mathrm{~cm}$ net $(100 \mu \mathrm{m}$ mesh) attached to a handle. Live organisms were placed in plastic containers with water from the same site and transported to the laboratory. Some specimens were kept alive for culturing while others were preserved in $70 \%$ ethanol for taxonomic identification. Mosquito species were identified according to keys by Darsie (1985) and Lane (1953). Copepods were identified following Reid (1985) and Ringuelet (1958), and their taxonomic identity was further confirmed by S. Menu-Marque, University of Buenos Aires, Argentina.

Culture of copepods and mosquitoes: Field collected gravid female copepods were placed individually in plastic containers with $150 \mathrm{~mL}$ of water. As nutrient source, we suspended circa $50 \mathrm{~g}$ of powdered rabbit chow in $250 \mathrm{~mL}$ of water and added $5 \mathrm{~mL}$ of this suspension to cultures. After hatching, the nauplii were transferred to new, $500 \mathrm{~mL}$-containers and raised until the adult stage. Larvae of A. aegypti and $C$. pipiens were obtained from colonies maintained by standard methods at CEPAVE, as described by Micieli et al. (2002).

Evaluation of predation capacity of copepods: Copepods collected from the abovementioned breeding places were exposed to individuals of the mosquito species sampled at each site. One adult female of each copepod species was exposed to young larvae in numbers according to availability in $10 \mathrm{~mL}$ of water in a plastic beaker. Three replicates were performed for each test. Predation rate was recorded daily. Any missing larvae was considered as eaten by copepods. Total mortality per container was scored as number of missing larvae plus those dead (killed but not eaten by 
the copepod), divided by number of replicates. A beaker containing only larvae of the tested mosquito species served as untreated control. No food sources were added.

Laboratory predation trials: Predation capacity of copepods obtained from the field survey was estimated through predation trials, using immature individuals of $A$. aegypti and $C$. pipiens as prey. All experiments were conducted at $26 \pm 1{ }^{\circ} \mathrm{C}$ and a 12:12 hr (L:D) photoperiod. Dechlorinated tap water was used in all treatments. Four species of copepods were tested separately, with nine trials plus three controls (containers with larvae but without copepods) each. Numbers of missing larvae were compared by ANOVA, followed by Duncan's test for multiple comparisons between treatments (Sokal and Rohlf 1979).

Experiment one: To analyze predation by single copepods, one female adult, one male adult, and one late copepodid were tested each against 25 first-instar mosquito larvae in plastic containers (8 cm diameter) containing $150 \mathrm{~mL}$ of water.

Experiment two: Selected species of copepods were evaluated separately against all instars of $A$. aegypti and $C$. pipiens. One adult female copepod and 25 mosquito larvae of $1^{\text {st }}$, $2^{\text {nd }}, 3^{\text {rd }}$ or $4^{\text {th }}$ instar were placed in separate containers.

Experiment three: The preference of each copepod species for larvae of both mosquitoes species was tested by exposing 25 second instar larvae of $A$. aegypti and 25 second instar larvae of $C$. pipiens to one female of each copepod species in containers with $200 \mathrm{~mL}$ of water.

Experiments one, two and three lasted $24 \mathrm{~h}$ and the number of missing larvae on each trial was recorded.

Experiment four: Daily predation rate of each copepod species was examined during five-day tests. One female copepod was exposed to 25 early instar larvae in containers with $150 \mathrm{~mL}$ of water. Live larvae were counted every 24 hours. The remaining larvae were removed daily and replaced by a new batch of 25 larvae.
Copepod tolerance to desiccation: In this experiment, the survival capacity of targeted species of copepods was tested under dry conditions. We placed 50 copepods of each species into a plastic container ( $8 \mathrm{~cm}$ diameter) with $2 \mathrm{~cm}$ of sterilized sand sediment and 150 $\mathrm{mL}$ of water, at $25 \pm 1{ }^{\circ} \mathrm{C}$ and 12:12 h (L:D), with three replicates each (total: 30 containers). Twenty-four hours later, standing water was removed with a pipette. One of the replicates was maintained with water throughout the experiment. After a period of 15 or 30 days, the containers were flooded with water and the number of live copepods was recorded.

Copepod survival in water from artificial containers: In order to test the survival capacity of copepods in water from artificial containers without prey, the following experiment was performed. We emptied 25 flower vases from the Cemetery of La Plata, blended all contents in a single container, and filtered the water with a mesh $(100 \mu \mathrm{m})$. As a control, the same procedure was done using dechlorinated tap water. Fifteen adult copepods of each selected species were added to $100 \mathrm{~mL}$ of both kinds of water in plastic containers ( $8 \mathrm{~cm}$ diameter). Copepod mortality was recorded after 7, 14 and 21 days. Three replicates plus a control were used for each species (total: 16 containers).

\section{RESULTS}

Field survey: Table 1 shows the predatory capacity of copepods upon each mosquito species obtained from the field survey. Transient freshwater ponds contained natural populations of M. annulatus and Diacyclops uruguayensis Kiefer. At these sites, immature specimens of Ochlerotatus albifasciatus Macquart and Culex sp. were collected. Both copepod species preyed on first instar mosquito larvae.

In the permanent pools the following larvivorous cyclopoids were found: Acanthocyclops robustus Sars, Macrocyclops albidus Jurine, Mesocyclops longisetus Thiébaud and Metacyclops mendocinus Wierzejski. Additionally, Ectocyclops rubescens Brady, Eucyclops sp., Microcyclops sp. and Paracyclops sp. were 
TABLE 1

Copepods found in the field survey and their predatory capacity on local mosquito species from La Plata, Buenos Aires province

\begin{tabular}{|c|c|c|c|c|}
\hline Copepod species & Freshwater type & Mosquito species & $\begin{array}{c}\text { Second Instar } \\
\text { Larvae exposed (n) }\end{array}$ & $\begin{array}{c}\text { Mortality } \\
(\%)\end{array}$ \\
\hline Mesocyclops longisetus & Permanent pool & Culex sp. & 10 & 80 \\
\hline \multirow[t]{2}{*}{ Macrocyclops albidus } & \multirow[t]{2}{*}{ Rice field permanent pool } & Culex sp. & 10 & 80 \\
\hline & & A. albitarsis & 5 & 100 \\
\hline Acanthocyclops robustus & Permanent pool & Culex sp. & 10 & 70 \\
\hline Metacyclops mendocinus & Permanent pool & Culex sp. & 10 & 60 \\
\hline \multirow[t]{2}{*}{ Mesocyclops annulatus } & \multirow[t]{2}{*}{ Transient freshwater ponds } & O. albifasciatus & 7 & 87.5 \\
\hline & & Culex sp. & 10 & 100 \\
\hline Diacyclops uruguayensis & Transient freshwater ponds & O. albifasciatus & 7 & 71.7 \\
\hline Paracyclops sp. & $\begin{array}{l}\text { Artificial container } \\
\text { permanent pool, } \\
\text { Eryngium cabrerae, } \\
\text { ditch and rice field }\end{array}$ & $\begin{array}{l}\text { Culex sp. } \\
\text { C. pipiens } \\
\text { C. renatoi } \\
\text { A. albitarsis } \\
\text { A. aegypti }\end{array}$ & 10 & 0 \\
\hline Ectocyclops rubescens & $\begin{array}{l}\text { Permanent pool, } \\
\text { ditch, Eryngium cabrerae }\end{array}$ & $\begin{array}{l}\text { C. pipiens } \\
\text { C. renatoi } \\
\text { Culex sp. }\end{array}$ & 10 & 0 \\
\hline Eucyclops sp. & Permanent pool & Culex sp. & 10 & 0 \\
\hline
\end{tabular}

also collected, but these species did not prey upon Culex sp. larvae. Two copepod species, Paracyclops sp. and E. rubescens, occurred in ditches together with $C$. pipiens, but they were not larvivorous. In the rice field we collected Anopheles albitarsis Lynch Arribalzaga and Culex sp., which shared this habitat with $A$. robustus, M. albidus, E. rubescens, Eucyclops sp. and Microcyclops sp. Only A. robustus and $M$. albidus were predators of both mosquito species.

Paracyclops sp. was the only copepod collected in artificial containers, but no predation was detected on larvae of $A$. aegypti and $C$. pipiens living in the same container.

Two copepod species, Paracyclops sp. and E. rubescens, were found in the water-filled axils of E. cabrerae. Both copepod species were not able to kill Culex renatoi (Lane and Ramallo), the only mosquito found breeding in this habitat.

Laboratory predation tests: The copepod species selected for predation trials were
A. robustus, D. uruguayensis, M. albidus and M. longisetus. M. mendocinus was not tested because it was not possible to breed this species under laboratory conditions.

Predation capacity was observed in females and males of $A$. robustus and D. uruguayensis, but this capacity was not detected in late copepodids (Table 2).

Both species fed on early instar $A$. aegypti and $C$. pipiens (Table 3). The comparison of mean number of larvae (all instars) of both mosquito species consumed by $A$. robustus showed that larval instar was the only highly significant effect (two-way ANOVA: $\mathrm{F}=57.39$; $\mathrm{df}=3,64 ; \mathrm{p}<0.05)$, being non-significant $(\mathrm{p}>$ 0.05 ) the main effect of prey species and the interaction term. Post hoc comparisons among means resulted in three groups: $2^{\text {nd }}$ instar $A$. aegypti plus $3^{\text {rd }}$ and $4^{\text {th }}$ instars of both species, $2^{\text {nd }}$ and $3^{\text {rd }}$ instar $A$. aegypti and C. pipiens, and $1^{\text {st }}$ instar A. aegypti and C. pipiens (Fig. 1A). In contrast, for D. uruguayensis the main effects of both prey species $(\mathrm{F}=5.73 ; \mathrm{df}=1$, $64 ; \mathrm{p}=0.019)$ and larval instar $(\mathrm{F}=99.3 ; \mathrm{df}=3$, 
TABLE 2

Predatory capacity of adults and copepodids of four copepods species on first instar larvae of Aedes aegypti $(\mathrm{Aa})$ and Culex pipiens $(\mathrm{CP})$

\begin{tabular}{l|c|c|c|ccc|}
\hline & \multicolumn{2}{c}{ Female } & \multicolumn{2}{c}{ Male } & \multicolumn{2}{c}{ Copepodids } \\
Predatory capacity (\%) & Aa & $\mathrm{Cp}$ & $\mathrm{Aa}$ & $\mathrm{Cp}$ & Aa & $\mathrm{Cp}$ \\
\hline Mesocyclops longisetus & 38 & 40 & 4 & 6.6 & 16 & 16 \\
Macrocyclops albidus & 51.3 & 49.5 & 11.5 & 11 & 5 & 4 \\
Diacyclops uruguayensis & 21.5 & 25.6 & 1.3 & 2.6 & 0 & 0 \\
Acanthocyclops robustus & 25 & 17.3 & 5 & 3.3 & 1.3 & 2
\end{tabular}

TABLE 3

Predation by four copepod species on each larval instar of Aedes aegypti (Aa) and Culex pipiens (Cp) larvae in laboratory conditions. Each cell shows mean ( \pm 1 SE) of number of larvae dead after $24 \mathrm{~h}$ of exposure in three replicate beaker

\begin{tabular}{|c|c|c|c|c|c|c|c|c|}
\hline \multirow{3}{*}{ Copepod species } & \multicolumn{8}{|c|}{ Killed larvae (n) } \\
\hline & \multicolumn{2}{|c|}{ 1st. instar } & \multicolumn{2}{|c|}{ 2nd. instar } & \multicolumn{2}{|c|}{ 3rd. instar } & \multicolumn{2}{|c|}{ 4th. instar } \\
\hline & $\mathrm{Aa}$ & $\mathrm{Cp}$ & $\mathrm{Aa}$ & $\mathrm{Cp}$ & $\mathrm{Aa}$ & $\mathrm{Cp}$ & $\mathrm{Aa}$ & $\mathrm{Cp}$ \\
\hline M. longisetus & $14.5 \pm 1.4$ & $12 \pm 1.05$ & $6.6 \pm 1$ & $7 \pm 1$ & $3.6 \pm 0.8$ & $3.1 \pm 1$ & $1 \pm 1$ & $1.33 \pm 0.7$ \\
\hline M. albidus & $12.8 \pm 2.8$ & $12.5 \pm 1.3$ & $7 \pm 1$ & $10.7 \pm 2.6$ & $3.2 \pm 1.1$ & $2.4 \pm 1.3$ & $0.55 \pm 0.5$ & $0.57 \pm 0.4$ \\
\hline D. uruguayensis & $5.6 \pm 2.1$ & $6.33 \pm 1$ & $4.1 \pm 0.68$ & $5 \pm 1.5$ & 0 & $0.4 \pm 0.5$ & 0 & 0 \\
\hline A. robustus & $5.33 \pm 2.3$ & $6.1 \pm 2$ & $3.33 \pm 0.7$ & $3 \pm 1.2$ & $0.6 \pm 0.7$ & $0.6 \pm 0.5$ & 0 & 0 \\
\hline
\end{tabular}

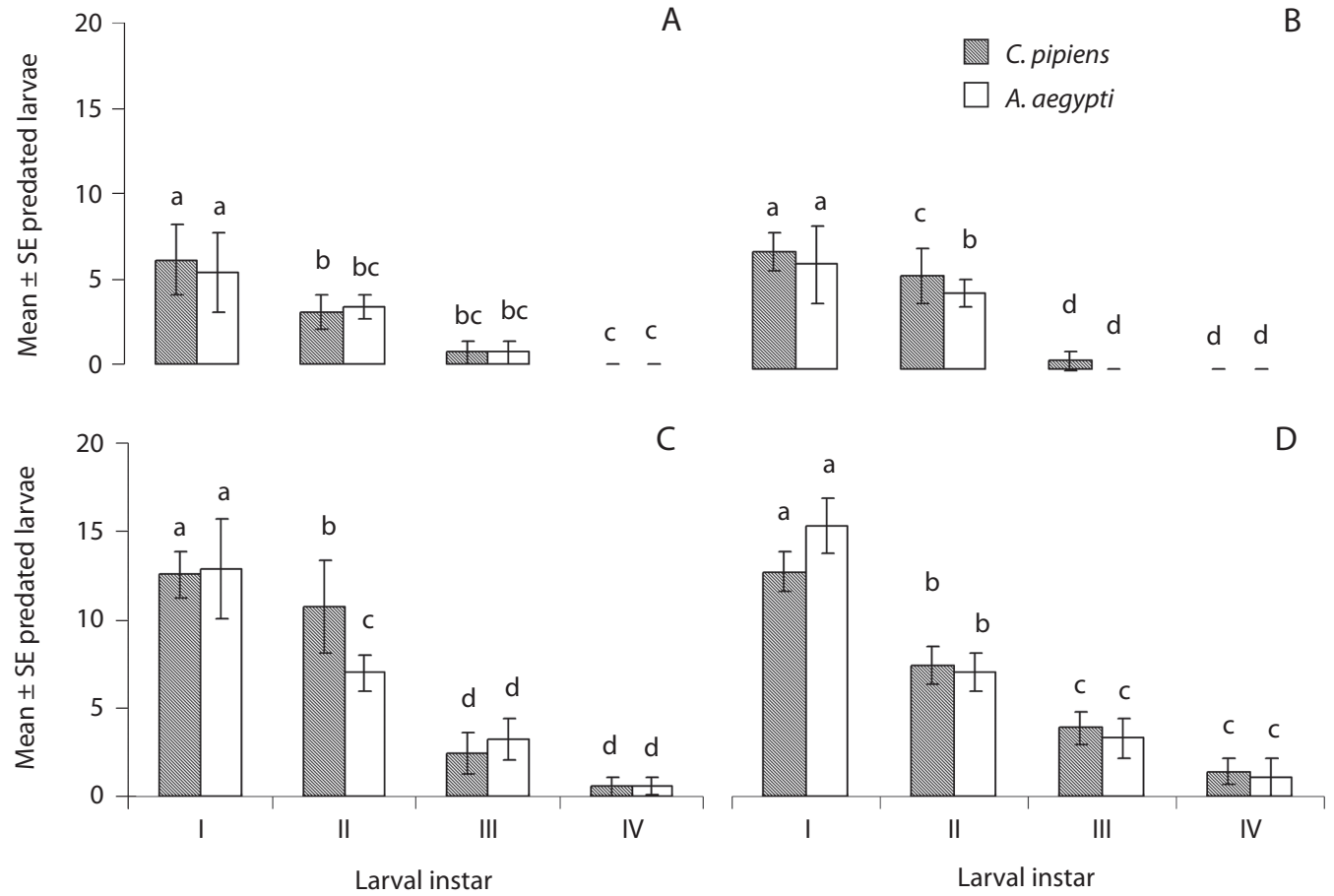

Fig. 1. Predation by (A) A. robustus, (B) D. uruguayensis, (C) M. albidus and (D) M. longisetus on instars I to IV of $A$. aegypti and C. pipiens. Means with different letters are significantly different after Duncan's test $(\mathrm{p}<0.05)$. 
64; $\mathrm{p}<0.05)$ were significant, whereas interaction was non-significant $(\mathrm{F}=2.5 ; \mathrm{df}=3,64 ; \mathrm{p}=$ 0.066). Comparisons among means showed four homogeneous groups: $3^{\text {rd }}$ and $4^{\text {th }}$ instar $C$. pipiens and $A$. aegypti, $2^{\text {nd }}$ instar $A$. aegypti, $2^{\text {nd }}$ instar $C$. pipiens, and $1^{\text {st }}$ instars of both mosquito species (Fig. 1B).

A. robustus yielded an overall larval mortality of $17 \%$ for $A$. aegypti and $25 \%$ for $C$. pipiens. D. uruguayensis consumed $21.5 \%$ A. aegypti and $28 \%$ C. pipiens larvae. Differences in daily mortality were not significant across days of the experiment $(\mathrm{p}>0.05)$. Thus, daily mortality during five days was constant (Figs. 2 and 3). $A$. robustus preyed upon $4.69 \pm 1.11 \mathrm{~A}$. aegypti and $5.01 \pm 2.01$ C. pipiens larvae per day. D. uruguayensis preyed upon $3.8 \pm 1.4 \mathrm{~A}$. aegypti and $4.5 \pm 1.3$ C. pipiens larvae per day. Differences were not significant between mean numbers of killed larvae of $C$. pipiens and $A$. aegypti when exposed to one $A$. robustus or $D$. uruguayensis female copepod in the same container.

When predation by $M$. albidus on each instar and prey species was compared, a twoway ANOVA showed that the effects of prey species $(\mathrm{F}=23.6 \mathrm{df}=1,64, \mathrm{p}<0.05)$ and larval instar $(\mathrm{F}=213.3 ; \mathrm{df}=3,64 ; \mathrm{p}<0.05)$, as well as their interaction $(\mathrm{F}=22.0 ; \mathrm{df}=3,64 ; \mathrm{p}<0.05)$, were highly significant. Duncan's test showed four groups of means: $3^{\text {rd }}$ and $4^{\text {th }}$ instars of $C$. pipiens and $A$. aegypti, $2^{\text {nd }}$ instar $A$. aegypti, $2^{\text {nd }}$ instar $C$. pipiens and $1^{\text {st }}$ larval instars of $C$. pipiens and A. aegypti (Fig. 1C).

Adult males have predatory capacity, but the latter was not observed in copepodids (Table 2). No differences in mortality rates among mosquito species were found when exposed to one copepod in the same container ( $>>0.05$ ). Total mortality averaged $29.7 \%$ for A. aegypti and $24.4 \%$ for C. pipiens. The predatory effectiveness of $M$. albidus against early $A$. aegypti larvae decreased across the five days of the experiment. The maximum larval mortality was recorded on the first day $(17.25 \pm 0.32$ larvae), and there were significant differences across days when mortality was compared along the five days of the trial $(\mathrm{F}=4.13 ; \mathrm{df}=4$, $40 ; p=0.0064)$ (Fig. 4).

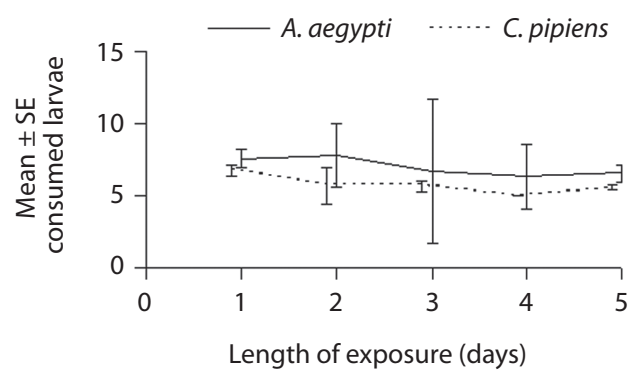

Fig. 2. Predation by D. uruguayensis on A. aegypti and $C$. pipiens first instars during five days. Means are not significantly different $(\mathrm{p}<0.05)$.

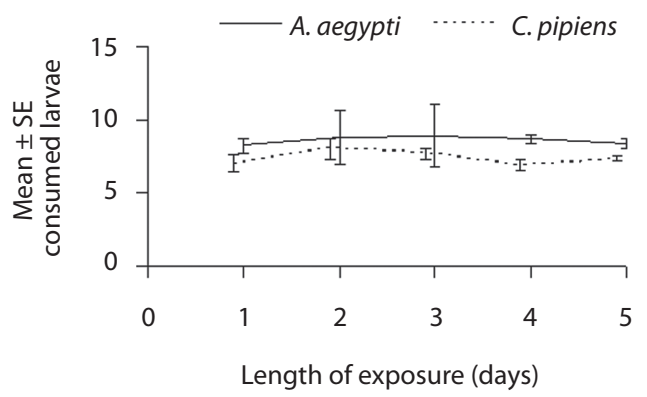

Fig. 3. Predation by $A$. robustus on A. aegypti and $C$. pipiens first instars during five days. Means are not significantly different $(\mathrm{p}<0.05)$.

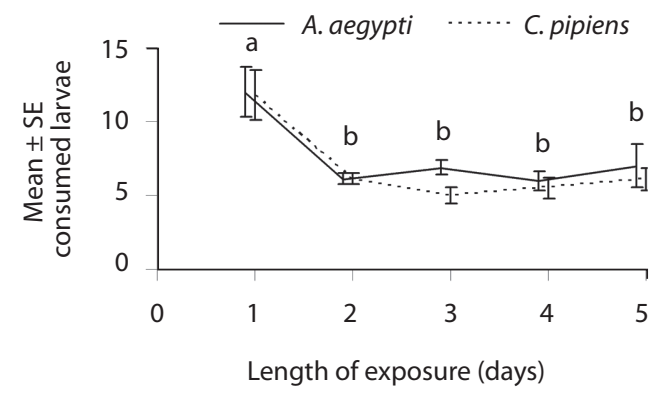

Fig. 4. Predation by M. albidus on A. aegypti and C. pipiens first instars during five days. Means with different letters are significantly different after Duncan's test $(\mathrm{p}<0.05)$. 
Adult females of $M$. longisetus preyed on both mosquitoes species. ANOVA showed that the main effect of prey instar was highly significant $(\mathrm{F}=236.17 ; \mathrm{df}=3,64 ; \mathrm{p}<0.05)$ but neither the effect of prey species nor the interaction (prey species $\mathrm{x}$ larval instar) were significant $(p<0.05)$. Post hoc comparisons showed significant differences among three groups of means for both mosquito species: $3^{\text {rd }}$ and $4^{\text {th }}$ instar, $2^{\text {nd }}$ instar, and $1^{\text {st }}$ instar (Fig. 1D). Mortality averaged $38 \%$ for A. aegypti larvae and $39.5 \%$ for $C$. pipiens. Adult males and late copepodids also showed killing capacity, although the mean number of larvae they preyed upon was lower (Table 2). The comparison of predatory effectiveness of $M$. longisetus on $C$. pipiens and $A$. aegypti living in the same container showed no significant differences in predation rates $(\mathrm{F}=0.68 ; \mathrm{df}=1 ; \mathrm{p}=0.476)$. The mean daily number of early instar larvae consumed by one $M$. longisetus female during five days was $5.22 \pm 1.8$ for $C$. pipiens and 6.75 \pm 0.24 for $A$. aegypti. M. longisetus consumed $14.34 \pm 0.7 \mathrm{~A}$. aegypti larvae, and $12.07 \pm 1.2$ C. pipiens larvae in the first day (Fig. 5). Significant differences were detected between the first day of exposure and the following days $(\mathrm{F}=19.101 ; \mathrm{df}=4,40 ; \mathrm{p}=0.0003)$, thus predation was not constant during the trial period.

Copepod tolerance to desiccation: No mortality was recorded for A. robustus during the experiment. D. uruguayensis showed $100 \%$ survival after 15 days, and $90 \%(n=45)$ after 30 days. Eighty percent of $M$. longisetus $(\mathrm{n}=$ 40) survived after 15 days and $60 \%(n=30)$ after 30 days in this trial. Mortality of M. albi$d u$ sas $100 \%(\mathrm{n}=50)$ after 15 days. Copepod mortality was null in containers holding water throughout the experiment.

Copepod tolerance to water from artificial containers: No mortality occurred in A. robustus kept in water from flower vases during 7, 14 and 21 days. For D. uruguayensis the mortality rate was $20 \%$ after 14 days, and $40 \%$ after 21 days. For M. longisetus kept in containers with water from cemetery vases,

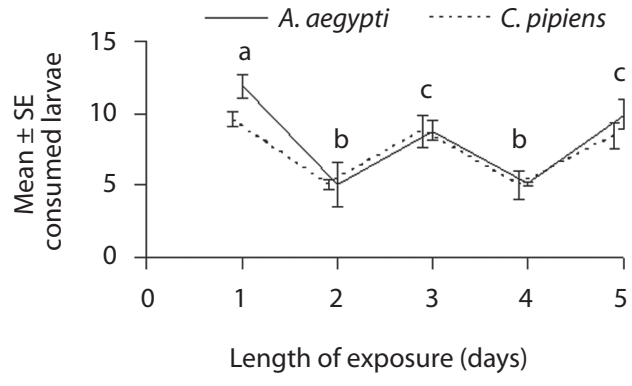

Fig. 5. Predation by M. longisetus on A. aegypti and $C$. pipiens first instars during five days. Means with different letters are significantly different after Duncan's test $(\mathrm{p}<$ $0.05)$.

$20 \%$ mortality was observed after 14 days. $M$. albidus showed $40 \%$ mortality after 14 days and this percentage was maintained until day 21. No mortality was detected in any copepod species bred in dechlorinated tap water.

\section{DISCUSSION}

The most diverse natural assembly of larvivorous cyclopoids was found in permanent pools from the study area, whereas only two predator copepod species were found in transient freshwater ponds. This was not unexpected because in general, more stable habitats are more diverse in terms of number of species, compared to habitats subject to fluctuations (Connell and Orias 1964). The contribution of predation by members of this assemblage to the overall mosquito larval mortality is unknown, and is worthy of complementary research in field conditions. No larvivorous copepods were found in artificial containers and drainage ditches, which are the main breeding habitats for $A$. aegypti and $C$. pipiens. This absence might be explained because the particular characteristics of these man-made habitats, such as their isolation from other water bodies, make it difficult for copepods to gain access to them.

The copepods E. rubescens, Eucyclops sp., Microcyclops sp., and Paracyclops sp. did not consume mosquito larvae under laboratory 
conditions, so they were discarded from further trials. Their low predatory capacity can be explained by the small size of these species (Marten and Reid 2007). The local species $A$. robustus, D. uruguayensis, M. albidus, and $M$. longisetus showed predatory capacity upon mosquito larvae, and consequently were selected for further investigation. A. robustus and $D$. uruguayensis were less effective predators on mosquito larvae than M. albidus and $M$. longisetus. These four copepod species preyed mainly on early instar larvae. The almost null predatory capacity upon older larvae was not surprising, considering that copepod cyclopoids are generally not large enough to kill third and fourth instar mosquito larvae. Low predation rates of copepods on late instar mosquito larvae has been reported by previous authors (Marten et al. 1989, 1994, Schreiber et al. 1996, Manrique-Saide et al. 1998, Soumare et al. 2004). The predatory capacity of adult female copepods of the studied species was higher than that of adult males and copepodids, perhaps due to their larger size, and/or higher mobility or aggressive behavior.

We did not find any predatory preferences of copepods for either of the tested mosquito species, A. aegypti or C. pipiens. Our results are not in agreement with those reported by Micieli et al. (2002), who found that $M$. annulatus preyed preferentially on larvae of A. aegypti compared to those of $C$. pipiens. A preference of this copepod for specific prey was also found by Soumare et al. (2004) in laboratory studies of $M$. longisetus adults, using Aedes albopictus Skuse and Culex quinquefasciatus Say larvae as prey. In our experiments we did not observe a differential attack rate among preys, perhaps due to the small size of our experimental containers. Any differential response of prey items could be cancelled by a forced, extremely short distance between individual predator and preys, determined by the size of our experimental container.

D. uruguayensis is known from Uruguay and Brazil (Reid 1998) and has recently been found in Argentina (Menu-Marque, personal communication). Results for this species are novel because it has not been studied before as a mosquito predator. Our results on the predatory capacity of $D$. uruguayensis were similar to those of other studies on congeneric species (Marten et al. 1989, Marten 1989, 1990a, 1990b, Andreadis and Gere 1992). Given that D. uruguayensis inhabits ephemeral pools, its capacity to survive dry conditions is not surprising. However, the relatively high mortality recorded for this copepod species in water from flower vases reduces the possibility of using it for the control of mosquitoes breeding in small human-made containers.

A. robustus is a Neotropical copepod (Menu-Marque 2001) that showed a predatory capacity similar to that observed in Acanthocyclops vernalis Fischer. Previous studies have demonstrated that $A$. vernalis feeds only on first instar mosquito larvae under laboratory conditions (Marten 1989, 1990a, Andreadis and Gere 1992). In this work, we show that $A$. robustus is an efficient predator and can also survive both under desiccation conditions and in water from artificial containers.

M. longisetus is a Neotropical cyclopoid that has been reported to reduce larval populations of Anopheles albimanus Wiedemann in roadside ditches (Marten et al. 1989), as well as A. aegypti and A. albopictus in container habitats (Schreiber et al. 1993, Marten et al. 1994, Manrique-Saide et al. 1998). In our study, $M$. longisetus showed a good level of predation and its survival under desiccation was not severely reduced during 30 days. Mechanisms of tolerance to desiccation have been observed in species of Mesocyclops (Zhen et al. 1994). However, Gorrochotegui-Escalante et al. (1998) reported decreased survival of $M$. longisetus during the dry season in Mexico. Some mortality was recorded when $M$. longisetus was maintained in water from flower vases, but mortality was not high enough to reject this species as a potential mosquito control in small containers.

M. albidus is a copepod with a worldwide distribution (Menu-Marque 2001). It was found to be a predator with good killing power, 
in agreement with previous studies (Marten 1990b), but its inability to survive in dry conditions, plus the high mortality observed in the assays with water coming from cemetery vases, suggest a limited efficacy against $C$. pipiens and $A$. aegypti. Furthermore, this species could be particularly limited by temperatures exceeding $37^{\circ} \mathrm{C}$ (Marten et al. 1994), a characteristic that becomes important when considering their use as a biological control agent for tropical immature mosquitoes, such as $A$. aegypti.

In conclusion, $M$. albidus and $M$. longisetus show the highest predation rates, although the latter are not sustained along five days. The low resistance to desiccation of these copepods suggests that they are less appropriate to be used in small containers in which standing water may be absent for variable periods. On the other hand, A. robustus and D. uruguayensis, although they consume a lower number of prey, are more desiccation-resistant, tolerate water from containers, and their predation rates are approximately constant; consequently, these species are interesting predators to be considered for inclusion in the existing lists of larval mosquito enemies.

\section{ACKNOWLEDGMENTS}

We are grateful to CONICET (Buenos Aires, Argentina) for partially supporting this study (PIP 6055) and Silvina Menu-Marque for confirmation of copepod identity. MCT holds a doctoral fellowship from CONICET, Argentina.

\section{RESUMEN}

Se hizo una prospección de copépodos en La Plata, Argentina, con los objetivos de caracterizar la comunidad local de copépodos larvívoros en sitios de cría de mosquitos, e identificar nuevas especies depredadoras de los mosquitos de contenedores artificiales Aedes aegypti y Culex pipiens. La diversidad de ciclopoides larvívoros fue máxima en charcos permanentes. Se examinó la depredación por sexos y edad, la selectividad por especies de mosquito, y la tasa de depredación diaria durante cinco días en Acanthocyclops robustus, Diacyclops uruguayensis, Macrocyclops albidus y Mesocyclops longisetus. Los copépodos hembra presentaron la capacidad depredadora más alta. No se encontró preferencia por alguna especie de mosquito. De acuerdo al potencial de depredación en general, los copépodos se ordenan así: D. uruguayensis $<A$. robustus $<M$. albidus $<M$. longisetus. También se evaluó la tolerancia a la desecación del hábitat y la capacidad de resistir en agua de contenedores artificiales. D. uruguayensis y $A$. robustus sobrevivieron en condiciones de sequía, pero $D$. uruguayensis presentó menor supervivencia en agua de floreros de cementerio. M. albidus no sobrevivió condiciones de sequía y no toleró el agua extraída de contenedores artificiales. Los ciclopoides neotropicales D. uruguayensis and A. robustus son buenos candidatos y merecen investigación ulterior como agentes de control biológico de mosquitos.

Palabras clave: copépodos, mosquitos, depredación larval, control biológico, Argentina.

\section{REFERENCES}

Andreadis, T.G. \& M.A. Gere. 1992. Laboratory evaluation of Acanthocyclops vernalis (Thomasi) (Copepoda: Cyclopoidae) as predators of Aedes canadiensis and Aedes stimulans (Diptera: Culicidae). J. Med. Entomol. 29: 974-979.

Brown, M.D., B.H. Kay \& J.K. Hendrikz. 1991. Evaluation of Australian Mesocyclops (Cyclopoidea: Cyclopoidae) for mosquito control. J. Med. Entomol. 28: 618-623.

Connell, J.H. \& E. Orias. 1964. The ecological regulation of species diversity. Amer. Nat. 98: 399-414.

Darsie, R.F. 1985. Mosquitoes of Argentina. Part I. Keys for identification of adult females and fourth stages larvae in English and Spanish (Diptera: Culicidae). Mosq. Syst. 17: 153-253.

Gorrochotegui-Escalante, N., I. Fernandez-Salas \& H. Gomez-Dante. 1998. Field evaluation of Mesocyclops longisetus (Copepoda: Cyclopoidea) for the control of larval Aedes aegypti (Diptera: Culicidae) in Northeastern Mexico. J. Med. Entomol. 35: 699-703.

Lane, J. 1953. Neotropical Culicidae. Fac. Hyg. Saude Publ. Univ. São Paulo 2: 633-729.

Manrique-Saide, P., S. Ibañez-Bernal, H. Delfín-González \& V. Parra. 1998. Mesocyclops longisetus effects on survivorship of Aedes aegypti immature stages in car tyres. Med. Vet. Entomol. 12: 386-390.

Marten, G.G. 1989. A survey of cyclopoid copepods for control of Aedes albopictus larvae. Bull. Soc. Vector Ecol. 14: 232-236. 
Marten, G.G. 1990a. Evaluation of cyclopoid copepods for Aedes albopictus control in tires. J. Am. Mosq. Control Assoc. 6: 681-688.

Marten, G.G. 1990b. Elimination of Aedes albopictus from tire piles by introducing Macrocyclops albidus (Copepoda, Cyclopoidae). J. Am. Mosq. Control Assoc. 6: 689-693.

Marten, G.G., R. Astaiza, M.F. Suarez, C. Monje \& J.W. Reid. 1989. Natural control of larval Anopheles albimanus (Diptera: Culicidae) by the predator Mesocyclops (Copepoda: Cyclopoida). J. Med. Entomol. 26: 624-627.

Marten, G.G., G. Borjas, M. Cush, E. Fernández \& J.W. Reid. 1994. Control of larval Aedes aegypti in peridomestic breeding containers. J. Med. Entomol. 31: $36-44$.

Marten, G.G. \& J.W. Reid. 2007. Cyclopoid copepods. J. Am. Mosq. Control Assoc. 23: 65-92.

Marti, G.A., M.V. Micieli, A.C. Scorsetti, \& G. Liljesthrom. 2004. Evaluation of Mesocyclops annulatus (Copepoda: Cyclopoidea) as a control agent of Aedes aegypti (Diptera: Culicidae) in Argentina. Mem. Inst. Oswaldo Cruz 99: 535-540.

Menu-Marque, S. 2001. Datos biogeográficos y nuevas localidades de copépodos de la Familia Cyclopidae (Copepoda, Cyclopoida) de la Argentina. Physis 58: $37-41$.

Micieli, M.V., G.A. Marti \& J.J. García. 2002. Laboratory evaluation of Mesocyclops annulatus (Wierzejski, 1892) (Copepoda, Cyclopoidea) as predator of container-breeding mosquitoes in Argentina. Mem. Inst. Oswaldo Cruz 97: 835-838.

Nam, V.S., N.T. Yen, M. Holynska, J.W. Reid \& B.H. Kay. 2000. National progress in dengue vector control in Vietnam: Survey for Mesocyclops sp. (Copepoda), Micronecta sp. (Corixidae), and fish as biological control agents. Am. J. Trop. Med. \& Hyg. 62: 5-10.

Reid, J.W. 1985. Clave de identifiçao e lista de referencias bibliográficas para as espécies continentais sudamericanas de vida livre da ordem Cyclopoida (Crustacea, Copepoda). Bol. Zool. Univ. São Paulo 9: 17-143.
Reid, J.W. 1998. Redescription and first records from Brazil of Diacyclops uruguayensis Kiefer (Crustacea, Copepoda, Cyclopoidae). Rev. Brasileira Zool. 15: 757-766.

Ringuelet, R.A. 1958. Los crustáceos copépodos de las aguas continentales de la República Argentina. Sinopsis Sistemática, Contr. Cient. Fac. Cienc. Exac. Nat. Univ. B. Aires, Zool. 1: 35-126.

Riviere, F., B.H. Kay, J.M. Klein \& Y. Sechan. 1987. Mesocyclops aspericornis (Copepoda) and Bacillus thuringiensis var. israelensis for the biological control of Aedes and Culex vectors (Diptera: Culicidae) breeding in crab holes, tree holes, and artificial containers. J. Med. Entomol. 24: 425-430.

Schreiber, E.T., C.F. Hallmon, K.M. Eskridge \& G.G. Marten. 1996. Effects of Mesocyclops longisetus (Copepoda: Cyclopoidae) on mosquitoes that inhabit tires: influence of litter type, quality and quantity. Am. J. Trop. Med. \& Hyg. 12: 688-694.

Schreiber, E.T., W.L. Turner, A.M. Lopez, C.F. Hallmon \& G.G. Marten. 1993. Evaluation of two cyclopoid copepods for Aedes albopictus control in tires in the panhandle of Florida at low introduction rates. J. Fla. Mosq. Control Assoc. 64: 73-74.

Sokal, R.R. \& F.J. Rohlf .1979. Bioestadística. Principios y Métodos Estadísticos en la investigación biológica. Blume, Buenos Aires, Argentina.

Soumare, M.K., J.E. Cilek \& E.T. Schreiber. 2004. Prey and size preference of Mesocyclops longisetus (Copepoda) for Aedes albopictus and Culex quinquefasciatus larvae. J. Am. Mosq. Control Assoc. 20: $305-310$.

Suarez, M.F., D. Ayala, M.J. Nelson \& J.W. Reid. 1984. Hallazgo de Mesocyclops aspericornis (Daday) (Copepoda: Cyclopoidae) depredador de larvas de Aedes aegypti en Anapoima, Colombia. Biomédica 4: 74-76.

Zhen, T., C.D. Jenning \& B.H. Kay. 1994. Laboratory studies of desiccation resistance in Mesocyclops (Copepoda: Cyclopoida). J. Am. Mosq. Control Assoc. 10: 443-446. 